ДИМИТРИЧЕВА Ольга Ивановна - кандидат философских наук, старший научный сотрудник международной междисциплинарной научной лаборатории технологий социально-гуманитарных исследований, доцент кафедры философии, социологии и теории социальной коммуникации Нижегородского государственного лингвистического университета им. Н.А. Добролюбова (603155, Россия, г. Нижний Новгород, ул. Минина, 31a; Dimitr-olga@yandex.ru)

САВЧЕНКО Ирина Александровна - доктор социологическихнаук, доцент; начальникмеждународной междисциплинарной научной лаборатории технологий социально-гуманитарных исследований, профессор кафедры философии, социологии и теории социальной коммуникации Нижегородского государственного лингвистического университета им. Н.А. Добролюбова (603155, Россия, г. Нижний Новгород, ул. Минина, 31a); профессор кафедры психологии и педагогики Нижегородской академии МВД РФ (603144, Россия, г. Нижний Новгород, Анкудиновское ш., 3; tеosтасо@rambler.ru)

АХМАТГАТИН Анвар Амирович - кандидат педагогических наук, профессор; заведующий кафедрой физической культуры Иркутского национального исследовательского технического университета (664074, Россия, г. Иркутск, ул. Лермонтова, 83; ahmatgatin@list.ru)

УСТИНКИН Сергей Васильевич - доктор исторических наук, профессор; декан факультета международных отношений, экономики и управления, профессор кафедры международных отношений и политологии Нижегородского государственного лингвистического университета им. Н.А. Добролюбова (603155, Россия, г. Нижний Новгород, ул. Минина, 31а); директор Приволжкского филиала Федерального научно-исследовательского социологического центра РАН (603000, Россия, г. Нижний Новгород, пер. Холодный, 4; sv.ustinkin@gmail.com)

\title{
МОТИВАЦИОННАЯ СФЕРА СОВРЕМЕННОГО СТУДЕНТА В ФОКУСЕ СОЦИОЛОГИЧЕСКОГО АНАЛИЗА
}

\begin{abstract}
Аннотация. В статье представлены результаты социологического исследования мотивации студентов технического вуза. Авторы показывают, что мотивация российского студенчества претерпевает трансформацию в сторону потребительских мотивов. В большей мере представлен личный и престижный мотив, стремление на базе высшего образования получить доступ к материальным благам общества в столице либо за границей.
\end{abstract}

Авторы представляют сравнительный анализ мотивации российского студенчества и субкультур хикикомори и сатори. Положительной тенденцией является наличие у российских студентов мотивации, в то время как у субкультур хикикомори и сатори мотивация отсутствует.

Ключевые слова: мотивация, мотивационное ядро, студенчество, хикикомори, сатори, субкультуры

$\mathrm{O}$ дной из задач современной системы образования является воспитание критически мыслящей личности, стремящейся к саморазвитию и самообразованию на протяжении всей жизни. Развитию этих качеств посвящены исследования психологов, философов и социологов [Димитричева 2017].

Смена системы ценностей в обществе приводит к размыванию ценностей молодого поколения. Изменяются базовые ценности, в связи с этим для понимания изменений и прогнозирования возможных последствий трансформации ценностей у молодого поколения социологи регулярно изучают мотивационное ядро.

В настоящее время защищаются кандидатские и докторские диссертации по мотивации школьников и студентов, но опираются эти исследования либо на работы 3. Фрейда, А. Маслоу, либо на труды представителей советской школы (А.Н. Леонтьев, С.Л. Рубинштейн, Л.И. Божович, Д.Н. Узнадзе и др.)

Наиболее продуктивным является представление о мотивации как о слож- 
ной системе, которая имеет не только постоянные, базисные элементы, но и приобретенные в процессе жизнедеятельности. Мотивационная система не является неизменной, она находится в постоянном развитии. Именно так видели данное явление отечественные и зарубежные классики теории мотивации Дж. Аткинсон, Л.И. Божович, Б.И. Додонов, А. Маслоу.

Иерархия основных потребностей личности была впервые опубликована в 1943 г. А. Маслоу [Маслоу 2003] и до сих пор не потеряла своей актуальности. Ученый полагал, что высшие потребности могут быть удовлетворены только после удовлетворения потребностей низшего уровня - физиологических потребностей, потребности в безопасности, в привязанности, в самоуважении - и только на пятом уровне находится потребность в самоактуализации. По мысли А. Маслоу, потребность в самовыражении и самосовершенствовании заложена в человеке, он с ней рожден, но для ее актуализации необходимо удовлетворение потребностей предшествующих уровней.

На основе устойчиво доминирующих мотивов поведения формируется направленность личности. Мотивы - это такие условия, которые характеризуют какое-либо сравнительно узкое, частное и изменчивое отношение человека к определенным предметам и явлениям внешнего мира [Мерлин 1971: 12-13]. На основании устойчиво доминирующих мотивов поведения формируется направленность личности. Советские педагоги и психологи (С.Л. Рубинштейн, А.Н. Леонтьев, Е.П. Ильин, Л.И. Божович, Д.Н. Узнадзе и др.) внесли большой вклад в изучение феномена направленности личности. Они выделяли два основных типа направленности: положительную и негативную. С.Л. Рубинштейн полагал, что направленность включает два момента: предметное содержание, обозначающее определенный предмет направленности, и напряжение - динамическую тенденцию, определяющую источник направленности [Рубинштейн 2000: 141].

Моральная направленность личности - сложное целостное образование, состоящее из разнообразных по нравственному содержанию, силе и волевой обеспеченности чувств, стремлений, потребностей. Одни из них могут устойчиво занимать лидирующее положение, другие - играть подчиненную, второстепенную роль, что находит свое выражение в той или иной направленности индивида. Иными словами, направленность личности - это доминирующие мотивы поведения.

Кроме этой классификации, существует и другая. Т.Е. Конникова выделяет личную и коллективную направленность [Конникова 1968: 3-5], М.С. Неймарк, кроме коллективной (общественной, гуманистической, альтруистической) и личной (эгоистической, престижной), выделяет деловую (бескорыстный интерес к делу) [Неймарк 1975: 12-13].

На примере Иркутского национального исследовательского технического университета (ИРНИТУ) рассмотрим мотивационную сферу современных студентов, получающих специальность «Горное дело». Специалисты горного дела востребованы в российских и зарубежных компаниях. Выпускники могут работать мастерами участков, инженерами. Специалисты в горной промышленности востребованы в организациях, занимающихся разработкой газовых и нефтяных месторождений, горнодобывающих комбинатах, а также при добыче золота, алмазов, металлов.

Кроме того, инженеры-маркшейдеры необходимы при проектировании метрополитена, подземных коммуникаций. В процессе строительства специалист контролирует правильность ведения подземных работ, проводит измерения и корректирует отклонения от проекта.

Это работа для настоящих мужчин - ответственная, требующая принятия 
решений, от правильности расчетов зависят жизни людей, поэтому на эти специальности в основном идут юноши, девушек мало.

Рассмотрим на примере технического вуза, каковы мотивы поступления в институт, насколько ответственно студенты подошли к выбору будущей профессии, каковы их смысложизненные ориентиры и карьерные ориентации.

Результаты анкетирования. Исследование проводилось среди студентов 1-4-го курсов, обучающихся по очной форме обучения. Общее число опрошенных - 301 чел. в возрасте от 18 до 22 лет.

Часть информации о себе студенты могли указывать по желанию. Половина опрошенных ответили на вопрос о месте рождения, и из них 24,5\% родились в Иркутске или Иркутской обл., 23,5\% - в других областях.

Анкета содержала вопросы о планах на будущее. В частности, был задан вопрос, планируют ли студенты вступать в брак. Не собираются в принципе вступать в брак $6 \%$, в отдаленной перспективе - $1 \%$. В период обучения в вузе планируют вступление в брак только 4\%, уже женатых или замужних - только $2 \%$. Большинство студентов (53\%) планируют вступить в брак, когда обеспечат себя материально, причем указан высокий достаток для себя и для семьи. Также $17 \%$ планируют создать семью после окончания университета, когда закрепятся на работе, столько же обучающихся планируют создать семью ближе к 30 годам. Таким образом, ранние браки в планы молодых людей не входят. Подобные установки характерны для обществ, в которых произошел демографический переход к малодетным семьям. Позднее вступление в брак приводит к сокращению числа детей в семье и, в общем, к депопуляции в стране. Причем рост материального благосостояния не ведет к увеличению числа детей в семье. В перспективе - проблема сокращения рождаемости в ближайшем будущем.

После окончания вуза Вы хотели бы...

Из общего числа студентов 57\% связывают свою жизнь с приобретением материального достатка. После окончания вуза хотели бы уехать в столицу $21 \%$, уехать за границу - 16\% и уехать в северные районы для работы в течение длительного времени - 20\%. Итак, только $1 / 5$ студентов собираются связать свою жизнь с деятельностью по специальности, с преодолением сложных условий работы. $37 \%$ стремятся к жизни в комфортных условиях - либо в Москве, либо за границей.

$14 \%$ собираются остаться в городе, где получают образование, столько же собираются вернуться к родителям в другой город или остаться в городе, где учатся, поскольку здесь живут родители. Родители - важный фактор только для $14 \%$ студентов. Ни о чем не думают $9 \%$. «Все равно» $-3 \%$.

Таким образом, на данном этапе преобладающее большинство студентов поставили перед собой задачу получить образование с целью обеспечения материального достатка.

Чем бы я хотел заниматься в будущем?

Работать в соответствии с полученной инженерной специальностью хотели бы $53 \%$ опрошенных. $32 \%$ философски относятся к жизни - они ответили, что как сложится, так и будет. Действительно, в наше сложное время планы не всегда сбываются. Не хотят ни учиться, ни работать $5 \%$ - будущие маргиналы с высшим престижным образованием. 7\% имеют источник заработка, не связанный со специальностью. Сменить квалификацию собираются 4\%, поступить в магистратуру - 3\%, поступить в аспирантуру $-4 \%$.

В любом вузе всегда есть люди, которые не нашли себя в получаемой сфере образования, поэтому $4 \%$ желающих сменить квалификацию - это невысокий показатель.

53\% четко определились с выбором профессии. Это тоже хороший пока- 
затель зрелой личности, но таких только половина опрошенных. Еще один настораживающий факт - современные студенты технического вуза не ценят уровни образования, следующие за специалитетом. Поступить в магистратуру и аспирантуру планируют только 7\%.

Почему Вы решили изучать именно горное дело?

Как выяснилось, в выборе именно этого вуза большую роль сыграли баллы ЕГЭ - 64\% проходили по баллам в этот вуз.

$78 \%$ отдали предпочтение этому вузу, потому что здесь много бюджетных мест. Романтические устремления тоже имеют место. $51 \%$ мечтали стать горными инженерами, $82 \%$ полагали, что обучение будет очень интересным, 65\% пошли в этот вуз из желания принести пользу обществу. $60 \%$ предпочитали учиться на специалитете, а не на бакалавриате, поэтому поступили в этот вуз именно на эту специальность. Лишь у $11 \%$ горное дело - семейная традиция.

Специальность выбрали родители всего для 6\% опрошенных студентов, $90 \%$ респондентов отметили, что родители не принимали участия в выборе вуза. $81 \%$ отмечают, что пример друзей также не оказал влияние на выбор вуза. У молодых людей прослеживается тенденция отмежеваться от родителей. Родители никак на них не влияют, ничего не определяют, принимают решения только сами молодые люди.

20\% отмечают, что подавали документы на другие специальности, но прошли только сюда. Столько же попали сюда случайно, $72 \%$ уверены, что попали сюда не случайно. $64 \%$ знали, что здесь нелегко учиться, а $13 \%$ были уверены в обратном.

Почему для обучения Вы выбрали именно этот вуз?

Студентам было разрешено выбрать несколько ответов. И не напрасно: в данном случае, действительно, студенты оказались полимотивированными. Основными мотивами для поступления в вуз стали хорошая репутация вуза $(91 \%)$ и престижность (94\%). На втором месте по мотивации поступления именно в этот вуз было наличие большого числа бюджетных мест (89\%). При этом $65 \%$ поступили сюда еще и потому, что из всех вузов, в которые студенты (еще будучи абитуриентами) проходили по баллам ЕГЭ, этот вуз оказался лучшим. В то же время 55\% не считали, что сюда будет легко поступить, $64 \%$ не считали, что здесь будет легко учиться.

Итак, подведем итоги. Молодые люди выбрали именно этот вуз, поскольку в нем предоставлено много бюджетных мест, вуз престижен и будущие студенты проходили по результатам ЕГЭ. А работать по специальности будут только 53\%, причем $37 \%$ планируют уехать в Москву или за границу, 65\% хотят принести пользу обществу, но поскольку $16 \%$ стремятся уехать за границу, то, видимо, пользу приносить они будут не российскому обществу.

Таким образом, главная мотивация - личная (эгоистическая и/или престижная). Многие студенты поступали на бюджетное обучение по результатам ЕГЭ в престижный вуз, чтобы вскоре уехать за границу или отправиться в Москву на заработки. Молодые люди хотят достичь материального достатка, опираясь на свои силы, получив высшее образование, говорят о том, что добьются всего сами, без помощи родителей и советов друзей. С одной стороны - это хорошо, говорит об активности, целеустремленности в жизни, но, с другой стороны, наверное, не мешало бы выказать больше уважения к родителям, которые произвели на свет таких умных детей. Родители являются ценностью, значимой составляющей в жизни $14 \%$ студентов.

Основные устремления молодежи сосредоточены на интересной учебе, а в перспективе - на интересной и престижной работе, которая позволит обеспечить индивидуальное материальное благополучие. Создание своей семьи 
и воспитание детей пока не входят в их планы, об этом мало задумываются, оставляют это на будущее (лет через 10 или позже).

Итак, у студентов доминирует материальная заинтересованность, они достаточно эгоистичны, о семье подумают когда-нибудь потом... Но все познается в сравнении. Сравним их устремления с направленностью некоторых молодежных субкультур.

«Сатори» - просветленные подростки. С 2010-х заговорили об этом поколении в Японии, а с 2017 г. - в России. Сатори - люди, которые ничего не хотят. Это интроверты. «Они не ездят на машинах. Они не хотят брендовых вещей. Они не занимаются спортом. Они не пьют спиртные напитки. Они не путешествуют. Любовь им безразлична» ${ }^{1}$. Сатори жалуются на обилие информации, которая мешает им понять, что же они хотят на самом деле. Они отрываются от реального мира и уходят в онлайн. У них низкий уровень запросов: «лишь бы на жизнь хватало». Молодые люди хотят, чтобы их семьи были счастливы, но не умеют строить отношения.

Связана такая ситуация, по мнению психологов, с большим числом разводов и с тем, что ребенка, как правило, одного, воспитывает женщина, на которую возлагается много обязанностей. Она много работает, и у нее не хватает времени на общение с ребенком.

С 1970-х гг. в Японии говорят о появлении субкультуры хикикомори. Молодые люди добровольно самоизолируются от общества, стремятся свести к минимуму любые контакты с людьми, в т.ч. с друзьями и родственниками. Они отказываются покидать родительский дом, изолируют себя от общества и семьи в отдельной комнате более 6 месяцев и не имеют работы.

Здесь существуют трудности: неизвестно, как они будут приспособлены к жизни в обществе, когда их родители начнут умирать. Эта проблема в Японии получила название «Вызов 2030 года» 2 .

Таким образом, если сравнивать с молодыми людьми, которые ничего не хотят, то ситуация с мотивацией студентов технического вуза выглядит лучше. Они адаптированы и социализированы, хотя и эгоистичны. Студенты ставят перед собой цели материального характера и стремятся к их достижению. Всего лишь 5\% студентов ничего не нужно - они не хотят ни учиться, ни работать. Надеемся, что через несколько лет эта цифра не увеличится. Для этого авторы статьи планируют провести повторное исследование. Главное, чтобы полное отсутствие мотивации не распространялось широко.

\section{Список литературы}

Димитричева О.И. 2017. Мотивация самовоспитания как основа развития интеллигентности. - Вестник Нижегородского государственного лингвистического университета им. Н.А. Добролюбова. Вып. 39. С. 108-119.

Конникова Т.Е. 1968. Формирование общественной направленности личности школьника как педагогическая проблема: О нравственном воспитании школьника. - Ученые записки ЛГПИ им. Герцена. Т. 341. С. 3-28.

Маслоу А.Г. 2003. Мотивация и личность. СПб: Питер. 392 с.

Мерлин В.С. 1971. Лекции по психологии мотивов человека. Пермь: ПГПУ. 119 с.

${ }^{1}$ Нармания Д., Токуяма А. 2017. Молодежь без стремлений: в России выросло «поколение сатори». - РИА Новости. 15.10.2017. Доступ: https://ria.ru/20171015/1506764905.html (проверено 23.08.2020).

2 Тарасенко Ю. 2020. Не выходи из комнаты: феномен хикикомори - свременных отшельников. Доступ: www.psychologies.ru > articles > ne-vyihodi-iz-komnatyi-fenomen-hi... (проверено 01.08.2020). 
Неймарк М.С. 1975. Некоторые проблемы личности школьника. М.: Знание. $64 \mathrm{c}$.

Рубинштейн С.Л. 2000. Основы общей психологии. СПб: Питер. 712 с.

DIMITRICHEVA Olga Ivanovna, Cand.Sci. (Philos.), Senior Research Associate of the International Cross-Disciplinary Laboratory of Research Methods in Social Science, Associate Professor of the Chair of Philosophy, Sociology and the Theory of Social Communication, Dobroljubov State Linguistics University of Nizhny Novgorod (31a Minina St, Nizhny Novgorod, Russia, 603155; Dimitr-olga@yandex.ru)

SAVCHENKO Irina Aleksandrovna, Dr.Sci. (Soc.), Head of the International Cross-Disciplinary Laboratory of Research Methods in Social Science, Professor of the Chair of Philosophy, Sociology and the Theory of Social Communication, Dobroljubov State Linguistics University of Nizhny Novgorod (31a Minina St, Nizhny Novgorod, Russia, 603155); Professor of the Chair of Philosophy, Nizhny Novgorod Academy of Ministry of Internal Affairs of Russian Federation (3 Ankudinovskoye Highway, Nizhny Novgorod, Russia, 603144)

aKHMATGATIN Anvar Amirovich, Cand.Sci. (Ped.), Full Professor; Head of the Chair of Physical Culture, National Research Irkutsk State Technical University (83 Lermontova St, Irkutsk, Russia, 664074; ahmatgatin@list.ru)

USTINKIN Sergey Vasilyevich, Dr.Sci. (Hist.), Full Professor; Dean of the Faculty of International Relations, Economies and Managements, Professor of the Department of International Relations and Political Science, Dobroljubov State Linguistics University of Nizhny Novgorod (31a Minina St, Nizhny Novgorod, Russia, 603155); Director of Volga Branch of the Federal Research Sociological Center of Russian Academy of Sciences (4 Holodny Lane, Nizhny Novgorod, Russia, 603000; sv.ustinkin@gmail.com)

\title{
MOTIVATIONAL SPHERE OF STUDENTS UNDER THE FOCUS OF SOCIOLOGICAL ANALYSIS
}

\begin{abstract}
The article presents the results of a sociological study of the motivation of students of a technical university. The authors present a comparative analysis of the motivation of Russian students and subcultures of hikikomori and satori. The motivation of Russian students is undergoing a transformation towards consumer motives. The article shows the predominance of personal and prestigious motives of the students, and their desire to gain access to the material benefits of society in the capital or abroad on the base of higher education. A positive trend is the presence of motivation, while the subcultures of hikikomori and satori have no motivation.
\end{abstract}

Keywords: motivation, motivational core, students, hikikomori, satori, subcultures 